$\not B$

J. bio-sci. 19: 1-6, 2011

ISSN 1023-8654

http://www.banglajol.info/index.php/JBS/index

\title{
PREVALENCE OF ABNORMAL GLYCEMIC AND LIPIDEMIC STATUS IN AN URBAN POPULATION OF BANGLADESH
}

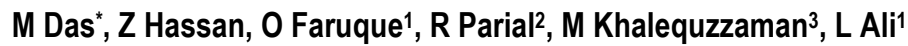 \\ Dept of Physiology and Molecular Biology, ${ }^{1}$ Dept of Biochemistry and Cell Biology, BIRDEM, Dhaka, \\ Bangladesh, ${ }^{2}$ Dept of Biochemistry and Molecular Biology, Chittagong University, ${ }^{3}$ nstitute of Biological \\ Sciences, Rajshahi University, Rajshahi, Bangladesh
}

\begin{abstract}
Context: Undiagnosed cases of diabetes mellitus constitute a major proportion of diabetic patients in the developing countries due to lack of proper screening and primary care facilities. Generation of evidence on undiagnosed cases is highly important for the estimation of the true burden of this disease.

Objectives: The present study was undertaken to explore the proportion of undiagnosed diabetes and associated disorders in a middle aged Bangladeshi population living in the capital city of Bangladesh.

Materials and Methods: Under a cross-sectional observational design a group of 254 middle aged (35-60 yrs) subjects (146 and 108) were included in the study who previously were unaware about the existence of diabetes or its complications. A 2-sample OGTT was done and blood glucose was estimated by glucose-oxidase method and Serum total cholesterol, HDL and TG by enzymatic colorimetric (Cholesterol Oxidase /Peroxidase, CHOD-PAP) method. Glycemic and other abnormalities were diagnosed and classified as per WHO criteria.

Results: Out of the total 254 subjects $34(15.1 \%)$ were found to have type 2 diabetes mellitus (T2DM) and 49 (19.29\%) were prediabetics (24.5\%-IFG, $75.5 \%$-IGT and $20.4 \%$ had combined IFG-IGT). WHR (the indicator of central obesity) was present in higher proportions of diabetic (93.9\%) and prediabetics (89.9\%) compared to $76.0 \%$ control $\left(\lambda^{2}=8.815 ; p=0.017\right)$. Male subjects had significantly higher central obesity compared to females both in the controls ( $t=3.929 ; p<0.0001)$ and in T2DM groups $(t=2.608 ; p=0.015)$. Dyslipidemia (judged by triglyceride value) was present among $64.7 \%$ in T2DM, $40.8 \%$ in Prediabetes and $47.9 \%$ in the Controls). In Prediabetes group $80 \%$ males had dyslipidemia compared to $20 \%$ females $(p=0.008)$.

Conclusion: Almost twice the proportion of reported diabetic and prediabetic cases in Bangladesh is still undiagnosed and a substantial proportion of these cases have generalized as well as central obesity and dyslipidemia.
\end{abstract}

Key words: Undiagnosed diabetes, Prediabetes, Obesity, Body Mass Index, Lipid abnormalities

\section{Introduction}

Undiagnosed diabetes may impose substantial public health implications because these subjects remain untreated and at risk for complications (Franse et al. 2001). Undiagnosed type 2 diabetes (T2DM) and impaired glucose regulation is reported to have substantial clinical importance (Harris et al. 2000, Wilson et al. 1991) and increase the risk of cardiovascular morbidity and mortality (Haffner et al. 1998; Unwin et al. 2002). Overt T2DM is preceded by two major asymptomatic indicators of imbalance in the metabolism of glucose: impaired glucose tolerance (IGT) and impaired fasting glucose (IFG) (ADA 2009). These two indicators, collectively labeled as prediabetes, are correlated but they may also appear separately (Valdez 2009). Similar to IFG and IGT, the early stages of T2DM are asymptomatic; consequently, people with the disease may go undiagnosed for prolonged periods. In the continuum of plasma glucose distributions (fasting or 2 hour), the escalation from prediabetes to T2DM is marked by a sharp increase in the risk of complications, which, in the long run, can seriously affect a variety of organs and tissues, such as eyes, kidneys, nerves, and blood vessels (large and small) (ADA 2009). Therefore, prediabetes and undiagnosed

*Corresponding author Email: godisvip@gmail.com 
T2DM are conditions for which screening can be helpful in preventing major health problems in a sizable portion of the population.

Diabetes is a dangerous disease when left undiagnosed and untreated. The prevalence of diabetes (20-79 years) in South--East Asia in 2010 was $7.6 \%$ and predicted to be $9.1 \%$ in 2030 and in Bangladesh $6.1 \%$ in 2010 and predicted to be $7.4 \%$ in 2030 (Shaw et al. 2010). Asian Indians (like people from India, Pakistan, Bangladesh and Sri Lanka) have surprisingly high prevalence of type 2 diabetes compared to Caucasians. For such an easy disease to detect and to screen for, it is amazing the number of people whose diabetes goes undetected and so untreated. Considering the dangers of not controlling diabetes, it is scary how many have diabetes undiagnosed. The United States estimated to have an undiagnosed diabetes population of $2.7 \%$ of the entire adult population over the age of 20 and prevalence of undiagnosed diabetes was similar among white and black men (9.1\%) (Franse et al. 2001). In Sardinian population, the prevalence of undiagnosed diabetes was $5.65 \%(5.20 \%$ and $6.15 \%$, females and males, respectively) (Muntoni et al. 2008). The estimated proportion of diabetes that was undiagnosed ranged from $28 \%$ using $\mathrm{HbA} 1 \mathrm{c}$ criteria in the 60 - to 74 -year age group to $43 \%$ based on oral glucose tolerance test criteria in the 75 -year and older group in England (Hayes et al. 2012). In Japan the prevalence of undiagnosed diabetes among men and women was $6.4 \%$ and $3.2 \%$, respectively (Bando et al. 2008). Generation of evidence on undiagnosed cases is highly important for the estimation of the true burden of diseases in a society. The present study was undertaken to explore the proportion of undiagnosed diabetes and associated disorders in a middle aged Bangladeshi population living in the capital city of Bangladesh.

\section{Materials and Methods}

Subjects, Anthropometric measurements and collection of blood samples: A total number of 254 (146 1 and 108 ㅇ) subjects (age 35-60 yrs) from Dhaka Metropolitan Area through personal contact between January to June 2011. The subjects did not have any diabetes check in last five years and were on sedentary life style. The volunteers were informed about the nature and purpose of the study and written consent obtained once they agreed to participate. Data were collected using a redesigned data collection sheet. Anthropometric measurements and blood pressure (BP) were recorded. Personal history, family history of diabetes and hypertension were also taken. Volunteer's height $(\mathrm{m})$ and weight $(\mathrm{kg})$, waist and hip circumference $(\mathrm{cm})$ were taken following standard procedure. BP (average of two independent measurements) was recorded using barometric Sphygmomanometer.

Overnight fasting (8-10 h) blood was collected between 8:00 to 9:00 hours and, subjects were given glucose drink ( $75 \mathrm{~g}$ glucose dissolved in $300 \mathrm{ml}$ of water) and second blood sample was drawn $2 \mathrm{~h}$ later (2h-PG). Serum separated was preserved at $-60^{\circ} \mathrm{C}$ until biochemical analyses.

Biochemical methods: Glucose (by glucose-oxidase) and serum total cholesterol, triglyceride and HDL cholesterol was measured by enzymatic colorimetric method (Hitachi 704 Automatic Analyzer, Hitachi Ltd., Japan using reagents of RANDOX Laboratories Ltd., UK). Serum LDL cholesterol was determined using Friedwald formula (Friedewald et al. 1972). The method was not applied in case of level of triacylglycerol exceeds $400 \mathrm{mg} / \mathrm{dL}$. Cut-off values for body mass index (BMI) (normal $\leq 22.9 \mathrm{~kg} / \mathrm{m}^{2} ;$ overweight $23-27.5$ and Obese $\geq 27.5$ ) and WHR (male- 0.90 and female-0.80) were used as per WHO guidelines for Asian population (WHO 2004). Blood pressure was measured by using a standard mercury sphygmomanometer. Weight and height were measured according to standard protocol and body mass index (BMI) was calculated (Garabed Eknoyan 2008).

Statistical methods: Taking into account the multistage stratified cluster random sampling procedure, total and gender-specific prevalence (95\% confidence intervals) of undiagnosed diabetes at the time of the study as well as prevalence of impaired fasting glucose (IFG), impaired glucose tolerance (IGT) and IFG/IGT were 
calculated. Univariate comparisons between the 3 patient groups were performed by using the $\lambda^{2}$ test for categorical variables. Statistical significance was set at $p<0.05$ and all values were two-sided. Statistical analysis was performed by the Statistical Package for Social Sciences (SPSS) version 17.0 for Windows.

\section{Results}

Out of the total 254 subjects $34(13.4 \%)$ were found to have T2DM and $49(19.3 \%)$ had prediabetes. Among the prediabetes, $24.5 \%$ had IFG, $75.5 \%$ had IGT and $20.4 \%$ had combined IFG-IGT (Table 1). In males, the proportion of T2DM and prediabetes were $55.9 \%$ and $57.1 \%$ respectively and corresponding values in females were $44.1 \%$ and $42.9 \%$ respectively (Table 2). Among the total subjects $1.57 \%$ subjects were underweight, $24.0 \%$ normal, $53.1 \%$ overweight and $21.7 \%$ obese. In case of male, proportion of overweight and obese in T2DM were $61.1 \%$ and $25.0 \%$ respectively and in prediabetes those were $57.1 \%$ and $59 \%$. In females, the proportions were $38.9 \%$ and $75.0 \%$ in case of T2DM and $42.9 \%$ and $50.0 \%$ in case of prediabetes respectively (Table 3 ). Male subjects had significantly higher central obesity compared to females both in controls $(t=3.929 ; p<0.0001)$ and in T2DM groups $(t=2.608 ; p=0.015)$ (Table 3). Dyslipidemia (judged by triglyceride value) was present among $64.7 \%$ in T2DM, $40.8 \%$ in prediabetes and $47.9 \%$ in the controls. Proportion of male and female subjects with dyslipidemia did not show a statistical difference in T2DM group and controls. In prediabetes group $80 \%$ males had dyslipidemia compared to $20 \%$ females $(\mathrm{p}=0.008)$ (Table 3).

Table 1. Proportion of diabetes and prediabetes among the total population

\begin{tabular}{lc}
\hline \multicolumn{2}{c}{ the total population } \\
Variables & $\mathrm{n}(\%)$ \\
\hline Total participants & 254 \\
Normal glucose tolerance & $171(67.3)$ \\
Diabetes mellitus & $34(13.4)$ \\
Prediabetes & $49(19.3)$ \\
Impaired fasting glucose (IGF) & $12(24.5)$ \\
Impaired glucose tolerance (IGT) & $37(75.5)$ \\
IFG+IGT & $10(20.4)$ \\
\hline
\end{tabular}

Table 2. Gender, age, BMI, WHR and blood pressure of the study subjects

\begin{tabular}{lccc}
\hline Variables & $\begin{array}{c}\text { Control } \\
(\mathrm{n}=171)\end{array}$ & $\begin{array}{c}\text { Prediabetes } \\
(\mathrm{n}=49)\end{array}$ & T2DM $(\mathrm{n}=34)$ \\
\hline Male & $99(58 \%)$ & $28(57.1 \%)$ & $19(55.9 \%)$ \\
Female & $72(42 \%)$ & $21(42.9 \%)$ & $15(44.1 \%)$ \\
Age $(\mathrm{yrs})$ & $45.2 \pm 7.1$ & $46.0 \pm 7.5$ & $47.9 \pm 8.9$ \\
BMI (Kg/m²) & $25.4 \pm 3.6$ & $25.3 \pm 3.2$ & $25.6 \pm 3.6$ \\
WHR & $0.92 \pm 0.07$ & $0.94 \pm 0.06^{*}$ & $0.93 \pm 0.03^{*}$ \\
Systolic BP $(\mathrm{mmHg})$ & $119 \pm 15$ & $116 \pm 14$ & $128 \pm 16^{*}$ \\
Diastolic BP $(\mathrm{mmHg})$ & $78 \pm 9$ & $79 \pm 10$ & $81 \pm 12$ \\
\hline
\end{tabular}

${ }^{*} \mathrm{p}<0.017, \mathrm{~T} 2 \mathrm{DM}=$ type 2 diabetes mellitus, BMI= body mass index, WHR= waist hip ratio, $\mathrm{BP}=$ Blood pressure

Table 3. Distribution of subjects on the basis of obesity markers (BMI and WHR) and by gender

\begin{tabular}{llccc|cccc}
\hline \multirow{2}{*}{ Groups } & \multicolumn{3}{c|}{ BMI- $\mathrm{n}(\%)$} & \multicolumn{2}{c|}{ WHR- $\mathrm{n}(\%)$} & \multicolumn{2}{c}{ Triglyceride- $\mathrm{n}(\%)$} \\
\cline { 3 - 8 } & & Normal & Over weight & Obese & Normal & C-Obesity & Normal & Hyper \\
\hline \multirow{3}{*}{ Male } & Control(99) & $57(57.6)$ & $38(38.4)$ & $4(4)$ & $12(12)$ & $87(88)$ & $48(48.5)$ & $51(51.5)$ \\
& T2DM(19) & $6(31.6)$ & $11(58)$ & $2(10.4)$ & $6(31.6)$ & $13(68.4)$ & $9(47.4)$ & $10(52.6)$ \\
& Prediabetic(28) & $8(28.6)$ & $16(57.1)$ & $4(14.3)$ & $8(28.6)$ & $20(71.4)$ & $12(43)$ & $16(57)$ \\
\hline \multirow{3}{*}{ Female } & Control(72) & $25(34.7)$ & $35(48.6)$ & $12(16.7)$ & $5(7)$ & $67(93)$ & $41(57)$ & $37(43)$ \\
& T2DM(15) & $2(13.3)$ & $7(46.7)$ & $6(40$ & $2(13.3)$ & $13(86.7)$ & $3(20)$ & $12(80)$ \\
& Prediabetic(21) & $4(19)$ & $12(57.1)$ & $5(23.9)$ & $4(19)$ & $17(81)$ & $17(81)$ & $4(19)$ \\
\hline
\end{tabular}

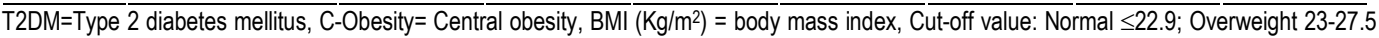
and Obese $\geq 27.5$ ). WHR $=$ waist hip ratio, Cut-off value: Male Normal $\leq 0.90 ;$ Female $\leq 0.80, M / F=$ male/ female, ${ }^{* *} p<0.001,{ }^{*} p<0.015$.

\section{Discussion}

Diabetes is a life threatening disease if it remains undiagnosed and untreated. However, much of diabetes remains undiagnosed (Rathmann et al. 2003, Joshy and Simmons 2006) and levels of hyperglycaemia below 
the diagnostic threshold for diabetes, IGT and IFG are associated with an excess risk of cardiovascular disease (Unwin et al. 2002, Harati et al. 2009). Such levels of hyperglycemia are also at high risk of progressing to Type 2 diabetes. Numerous studies have shown that diabetes mellitus is not identified and consequently inadequately treated in a substantial proportion of the patients in the general population (RojasRojas-Martínez et al. 2012). In our study, 15.1\% were found to have undiagnosed T2DM, 24.5\% had IFG, $75.5 \%$ had IGT and $20.4 \%$ had combined IFG-IGT (Table 1). In males, the proportion of T2DM and prediabetes were $55.9 \%$ and $57.1 \%$ respectively and corresponding values in females were in $44.1 \%$ and $42.9 \%$ (Table 2) which are higher than Iranian population (Hadaegh et al. 2008). Rahman et al. (2007) observed the total prevalence of type 2 diabetes in an urbanizing rural community in Bangladesh as $8.5 \%$, men showed higher prevalence $(9.4 \%)$ compare to women $(8.0 \%)$, whereas the overall prevalence of was $11.2 \%$ and IFG was $5.9 \%$ as recorded in urban area by Sayeed et al. (2007). The overall prevalence of DM was $16.7 \%$ with diagnosed DM being (10.7\%) and newly diagnosed DM being $(5.9 \%)$ of the Qatari population (Bener et al. 2009).

Clustering of pre-diabetes and diabetes is present in families of prediabetic subjects. So they should be taken as a major target for primary prevention of diabetes and prediabetes as like as first degree relatives of type 2 diabetic subjects (Shefin et al. 2011). Although there is increased awareness of diabetes in our population with improvement of education and access to medical care, but this was not sufficient to decrease the percent of undiagnosed cases. Undiagnosed T2DM is not milder than clinically detected diabetes (Rathmann et al. 2003). Hariss et al. (2000) in a review study reported that people with undiagnosed diabetes have substantial rates of risk factors for diabetes complications although they are not as hyperglycemic as are patients with diagnosed diabetes. In a rural population of Bangladesh Rahim et al. (2010) recorded the prevalence of IFG, IGT and newly detected T2DM were $1.3 \%, 2.0 \%$ and $7.0 \%$ respectively. IFG, IGT, IFG+IGT were more prevalent in females than males.

In our study, it was found that undiagnosed prediabetic and diabetic patients are of older age than normal population, which is supported by other study (Dong et al. 2005, Hadaegh et al. 2008, Nayak et al. 2011). We found that the total prevalence of diabetes was higher in male than female, a finding that is differ from a study in Iran (10\% in women vs. $8.1 \%$ in men) (Esteghamati et al. 2008) and similar to data of the U.S (Harris et al. 1998, Geiss et al. 2006) and Australia (Dunstan et al. 2002). The higher prevalence of metabolic syndrome was found in our male population although hypertriglyceride and obese female were found more than male in case of T2DM (Table 3,4). The higher prevalence of metabolic syndrome in our male may be the underlying cause for this sex difference (Azizi et al. 2003, Zabetian et al. 2007). Systolic blood pressure was significantly higher in diabetic subjects in comparison to normal subjects where as diastolic blood pressure did not show any significant difference among group (Table 2). This finding is similar to many other studies (Cushman 2010, Saadi et al. 2010, Joshi et al. 2012). The data from other authors showed a higher prevalence of overweight and other cardiovascular risk factors mainly in the group of undiagnosed diabetics (Meigs et al. 1998, Saydah et al. 2001, Tenenbaum et al. 2000). As the sample size was small so it is difficult to conclude on the prevalence of undiagnosed diabetes but this study will add some knowledge about the undiagnosed diabetes urban population of Bangladesh.

\section{Conclusions}

The data suggest that almost twice the proportion of reported diabetic and prediabetic cases in Bangladesh are still undiagnosed and a substantial proportion of these cases have generalized as well as central obesity and dyslipidemia. The proportion of undiagnosed cases can assume to be higher in rural areas due to lack of facilities and education. Thus, the true burden of undiagnosed diabetes in Bangladesh may be much higher and need further study and exploration considering these cases. 


\section{References}

ADA (American Diabetes Association). 2009. Standards of medical care in diabetes. Diabetes Care 32 Suppl 1, S13-61. http://dx.doi.org/10.2337/dc09-S013. PMid:19118286, PMCid:2613589

Azizi F, Salehi P, Etemadi A, Zahedi-AsI S. 2003. Prevalence of metabolic syndrome in an urban population: Tehran Lipid and Glucose Study. Diabetes Res Clin Pract 61(1), 29-37. http://dx.doi.org/10.1016/S0168-8227(03)00066-4

Bando Y, Kanehara H, Aoki K, Katoh K, Toya D, Tanaka N. 2008. Characteristics of undiagnosed diabetes mellitus in a population undergoing health screening in Japan: target populations for efficient screening. Diabetes Res Clin Pract 83, 341-346. http://dx.doi.org/10.1016/j.diabres.2008.11.033. PMid:19118911

Bener A, Zirie M, Janahi IM, Al-Hamaq AOAA, Musallamc M, Warehame NJ. 2009. Prevalence of diagnosed and undiagnosed diabetes mellitus and its risk factors in a population-based study of Qatar. Diabetes Res Clin Pract 84, 99-106. http://dx.doi.org/10.1016/j.diabres.2009.02.003. PMid:19261345.

Cushman WC, Evans GW, Byington RP, Goff DC, Grimm RH, Cutler JA, Simons-Morton DG, Basile JN, Corson MA, Probstfield JL, Katz L, Peterson KA, Friedewald WT, Buse JB, Bigger JT, Gerstein HC, Ismail-Beigi F. 2010. Effects of intensive blood-pressure control in type 2 diabetes mellitus. N Engl J Med 362, 1575-1585. http://dx.doi.org/10.1056/NEJMoa1001286. PMid:20228401.

Dong Y, Gao W, Nan H, Yu H, Li F, Duan W, Wang Y, Sun B, Qian R, Tuomilehto J, Qiao Q. 2005. Prevalence of Type 2 diabetes in urban and rural Chinese populations in Qingdao, China. Diabet Med 22, 1427-1433. http://dx.doi.org/10.1111/j.14645491.2005.01658.x. PMid:16176207

Dunstan DW, Zimmet PZ, Welborn TA, de Courten MP, Cameron AJ, Sicree RA, Dwyer T, Colagiuri S, Jolley D, Knuiman M, Atkins R, Shaw JE. 2002. The rising prevalence of diabetes and impaired glucose tolerance: the Australian Diabetes, Obesity and Lifestyle Study. Diabetes Care 25, 829-834. http://dx.doi.org/10.2337/diacare.25.5.829. PMid:11978676

Esteghamati A, Gouya MM, Abbasi M, Delavari A, Alikhani S, Alaedini F, Safaie A, Forouzanfar M, Gregg EW. 2008. Prevalence of diabetes and impaired fasting glucose in the adult population of Iran: National Survey of Risk Factors for Non-Communicable Diseases of Iran. Diabetes care 31(1), 96-98. http://dx.doi.org/10.2337/dc07-0959. PMid:17921357

Franse LV, Bari MD, Shorr RI, Resnick HE, Van Eijk JTM, Bauer DC, Newman AB, Pahor M. 2001. Type 2 Diabetes in Older WellFunctioning People: Who Is Undiagnosed? Data from the Health, Aging, and Body Composition Study. Diabetes Care 24, 20652070. http://dx.doi.org/10.2337/diacare.24.12.2065. PMid:11723084

Friedewald WT, Levy RI, Fredrickson DS. 1972. Estimation of the concentration of low-density lipoprotein cholesterol in plasma, without use of the preparative ultracentrifuge. Clin Chem 18, 499-502. PMid:4337382

Garabed Eknoyan. 2008. Adolphe Quetelet (1796-1874)-the average man and indices of obesity. Nephrol. Dial. Transplant. 23 (1), 47-51. http://dx.doi.org/10.1093/ndt/gfm517. PMid:17890752

Geiss LS, Pan L, Cadwell B, Gregg EW, Benjamin SM, Engelgau MM. 2006. Changes in incidence of diabetes in U.S. adults, 19972003. Am J Prev Med 30, 371-377. http://dx.doi.org/10.1016/j.amepre. 2005.12.009. PMid:16627124

Hadaegh F, Bozorgmanesh MR, Ghasemi A, Harati H, Saadat N, Azizi F. 2008. High prevalence of undiagnosed diabetes and abnormal glucose tolerance in the Iranian urban population: Tehran Lipid and Glucose Study. BMC Public Health 8, 176. doi:10.1186/14712458-8-176. http://www. biomedcentral.com/1471-2458/8/176. http://dx.doi.org/10.1186/1471-2458-8-176. PMid:18501007. PMCid:2413226

Haffner SM, Lehto S, Ronnemaa T, Pyorala K, Laakso M. 1998. Mortality from coronary heart disease in subjects with type 2 diabetes and in nondiabetic subjects with and without prior myocardial infarction. $N$ Engl $J$ Med 339, 229-234. http://dx.doi.org/10.1056/NEJM199807233390404. PMid:9673301

Harati H, Hadaegh F, Saadat N, Fereidoun Azizi F. 2009. Population-based incidence of Type 2 diabetes and its associated risk factors: results from a six-year cohort study in Iran. BMC Public Health 9, 186. http://dx.doi.org/10.1186/1471-2458-9-186. PMid:19531260, PMCid:2708154

Harris MI, Eastman RC. 2000. Early detection of undiagnosed diabetes mellitus: a US perspective. Diabetes Metab Res Rev 16(4), 230236. http://dx.doi.org/10.1002/1520-7560(2000)9999:9999<::AID-DMRR122>3.0.CO;2-W

Harris MI, Flegal KM, Cowie, CC, Eberhardt MS, Goldstein DE, Little RR, Wiedmeyer H-M, Byrd-Holt DD. 2000. Prevalence of Diabetes, Impaired Fasting Glucose, and Impaired Glucose Tolerance in U.S. Adults: The Third National Health and Nutrition Examination Survey, 1988-1994. Diabetes Care 21, 518-524. http://dx.doi.org/10.2337/diacare.21.4.518. PMid:9571335

Hayes L, Hawthorne G, Unwin N. 2012. Undiagnosed diabetes in the over-60s: performance of the Association of Public Health Observatories (APHO) Diabetes Prevalence Model in a general practice. Diabet Med 29, 115-120. http://dx.doi.org/10.1111/j.1464-5491.2011.03389.x. PMid:21781154 
Joshi SR, Saboo B, Vadivale M, Dani SI, Mithal A, Kaul U, Badgandi M, lyengar SS, Viswanathan V, Sivakadaksham N, Chattopadhyaya PS, Biswas AD, Jindal S, Khan IA, Sethi BK, Rao VD, Dalal JJ. 2012. Prevalence of diagnosed and undiagnosed diabetes and hypertension in India--results from the Screening India's Twin Epidemic (SITE) study. Diabetes Technol Ther 14, 815. http://dx.doi.org/10.1089/dia.2011.0243

Joshy G, Simmons D. 2006. The epidemiology of diabetes in New Zealand: Revisit to a changing landscape. N Z Med J 119(1235).

Meigs JB, Nathan DM, Wilson PWF, Cupples LA, Singer DE.1998. Metabolic risk factors worsen continuously across the spectrum of nondiabetic glucose tolerance: the Framingham Offspring Study. Ann Intern Med 128, $524-533$.

Muntoni SA, Atzori L, Mereu R, Manca A, Satta G, Gentilini A, Bianco P, Baule A, Baule GM, Muntoni S. 2008. Prevalence of diagnosed and undiagnosed diabetes mellitus and impaired fasting glucose in Sardinia. Acta Diabetologica 46, 227-231. http://dx.doi.org/10.1007/s00592-008-0081-4. PMid:1910732

Nayak HK, Vyas S, Solanki A, Tiwari H. 2011. Prevalence of type 2 diabetes in urban population of Ahmedabad, Gujarat. Indian J Med Specialities 2, 101-105.

Rahim MA, Khan AKA, Nahar Q, Ali SMK, Hussain A. 2010. Impaired fasting glucose and impaired glucose tolerance in rural population of Bangladesh. Bangladesh Med Res Counc Bull 36, 47-51. PMid:21473200

Rahman MM, Rahim MA, Nahar Q. 2007. Prevalence and risk factors of Type 2 diabetes in an urbanizing rural community of Bangladesh. Bangladesh Med Res Counc Bull 33, 48-54. PMid:18481438.

Rathmann W, Haastert B, Icks A, Lowel H, Meisinger C, Holle R, Giani G. 2003. High prevalence of undiagnosed diabetes mellitus in Southern Germany: target populations for efficient screening. The KORA survey 2000. Diabetologia 46(2), 182-189. PMid:12627316.

Rojas-Martínez R, Aguilar-Salinas CA, Jiménez-Corona A. 2012. Optimal cutoff points for the detection of undiagnosed type 2 diabetes, hypertension and metabolic syndrome in Mexican adults. Salud Publica Mex 54, 13-19. PMid:22286824.

Saadi H, Al-Kaabi J, Benbarka M, Khalili A, Almahmeed W, Nagelkerke N, Salustri A, Abdel-Wareth L, Al Essa A, Yasin J, Al-Dabbagh B, Kazam E. 2010. Prevalence of undiagnosed diabetes and quality of care in diabetic patients followed at primary and tertiary clinics in Abu Dhabi, United Arab Emirates. Rev Diabet Stud 7, 293-302. http://dx.doi.org/10.1900/RDS.2010.7.293. PMid:21713317, PMCid:3143544

Saydah SH, Loria CM, Eberhardt MS, Brancati FL. 2001. Subclinical states of glucose intolerance and risk of death in the US. Diabetes Care 24, 447-453. http://dx.doi.org/10.2337/diacare.24.3.447. PMid:11289466

Sayeed MA, Mahtab H, Khanam PA, Latif ZA, Banu A, Khan AK. 2007. Prevalence of diabetes and impaired fasting glucose in urban population of Bangladesh. Bangladesh Med Res Counc Bull 33, 1-12. PMid:18246729.

Shaw JE, Sicree RA, Zimmet PZ. 2010. Diabetes Atlas: Global estimates of the prevalence of diabetes for 2010 and 2030. Diabetes Res Clin Pract 87, 4-14. http://dx.doi.org/10.1016/j.diabres.2009.10.007. PMid:19896746

Shefin SM, Faruque MO, Khandker SH, Latif ZA, Ali L. 2011. First degree relatives of Bangladeshi prediabetic subjects are at increased risk for developing glucose intolerance. J Bangladesh Coll Physi Surg, 29, 21-26

Tenenbaum A, Motro M, Fisman EZ, Boyko V, Mandelzweig L, Reicher-Reiss H, Graff E, Brunner D, Behar S. 2000. Clinical impact of borderline and undiagnosed diabetes mellitus in patients with coronary artery disease. Am J Cardiol 86, 1363-1366. http://dx.doi.org/10.1016/S0002-9149(00)01244-3

Unwin N, Shaw J, Zimmet P, Alberti KG. 2002. Impaired glucose tolerance and impaired fasting glycaemia: the current status on definition and intervention. Diabetic Med19, 708-23. http://dx.doi.org/10.1046/j.1464-5491.2002.00835.x. PMid:12207806

Valdez, R. 2009. Detecting Undiagnosed Type 2 Diabetes: Family History as a Risk Factor and Screening Tool. J Diabetes Sci Technol $3(4), 722-726$.

WHO. 2004. Appropriate body $\square$ mass index for Asian populations and its implications for policy and intervention strategies. Lancet 363(9403), 157-163. http://dx.doi.org/10.1016/S0140-6736(03)15268-3

Wilson PW, Cupples LA, Kannel WB. 1991. Is hyperglycemia associated with cardiovascular disease? The Framingham Study. Am Heart J 121, 586-590. http://dx.doi.org/10.1016/0002-8703(91)90729-2

Zabetian A, Hadaegh F, Azizi F. 2007. Prevalence of metabolic syndrome in Iranian adult population, concordance between the IDF with the ATPIII and the WHO definitions. Diabetes Res Clin Pract 77(2), 251-257. http://dx.doi.org/10.1016/j.diabres.2006.12.001. PMid:17234299. 